\title{
Notes on Romanization and Notations
}

1. Japanese names are stated in the Japanese order (i.e., surname followed by given name).

2. Unless otherwise noted, translations are mine.

3. Shōdan 小段 brackets, delineated by Yokomichi ([1987a] 1993, 4:329) and Tōyō Ongaku Gakkai (1990, 4:26-27), are as follows: [ ] for utai-goto 謡事; [ ] for hayashi-goto 啐隹子事; ${ }^{1}$ and \{ \} for shijimagoto 無言事. Furthermore, \langle\rangle are used for titles of Noh plays in Japanese.

4. The Kō-ryū kotsuzumi and Takayasu-ryū ōtsuzumi drum strokes/ sounds are as follows:

Kō-ryū kotsuzumi (Kō Yoshimitsu [1956] 2004, 1)

chi f (kan) high; weak •

ta タ (kashira) high; strong $\Delta$

$\mathrm{pu} フ ゚$ (hodo) lower; quite weak

poポ (otsu) low; strong ○

tsu ツ

Takayasu-ryū ōtsuzumi (Yasufuku Haruo [1960] 1968)

$\begin{array}{lll}\text { tsu ツ } & \text { soft } & \bullet \\ \text { chon チョン } & \text { loud } & \Delta \\ \text { don ドン } & \text { soft } & \bullet\end{array}$

1. The extra space seen before and after the [ ] brackets is due to the font. A Japanese font has been used for these brackets because they do not exist in English fonts. 
5. The Kō-ryū kotsuzumi and Takayasu-ryū òtsuzumi drummers' kakegoe (calls) 力ケ声 (Bethe and Brazell [1978] 1990, 66) are as follows:

a. There are two standard drum kakegoe; these are traditionally notated as below, where the vowel pronunciations are closer to "o" than to "a":

1. "ya" often appears before beats one and five, dividing the eightbeat groupings into halves.

2. "ha" comes before beats two, three, six, and seven and, for the shoulder drum, also before beat eight.

b. There are two special kakegoe, which usually precede oddnumbered beats and are played in striking patterns:

1. "iya"

2. "уо-i" 